Cortés, E., Manire, C.A., Hueter, R.E., 1996. Diet, feeding habits, and diel feeding chronology of the bonnethead shark, Sphyrna tiburo in southwest Florida. Bulletin of Marine Science 58, 353-367.

Davis, J.A., May, M.D., Greenfield, B.K., Fairey, R., Roberts, C., Ichikawa, G., Stoelting, M.S., Becker, J.S., Tjeerdema, R.S., 2002. Contaminant concentrations in sport fish from San Francisco Bay, 1997. Marine Pollution Bulletin 44, 1117-1129.

Fisk, A.T., Tittlemier, S.A., Pranschke, J.L., Norstrom, R.J., 2002. Using anthropogenic contaminants and stable isotopes to assess the feeding ecology of greenland sharks. Ecology 83, 2162-2172.

Folch, J., Lees, M., Sloane Stanley, G.H., 1957. A simple method for the isolation and purification of total lipids [sic] from animal tissues. Journal of Biological Chemistry 226, 497-509.

Gelsleichter, J., Manire, C.A., Szabo, N.J., Cortés, E., Carlson, J., Lombardi-Carlson, L., 2005. Organochlorine concentrations in bonnethead sharks (Sphyrna tiburo) from four Florida estuaries. Archives of Environmental Contamination and Toxicology 48, 474-483.

Gelsleichter, J., Szabo, N.J., Morris, J.J. 2007. Organochlorine contaminants in juvenile sandbar (Carcharhinus plumbeus) and blacktip (Carcharhinus limbatus) sharks from major nursery areas on the east coast of the United States. In: McCandless, C., Kohler, N., Pratt Jr., H.L., Shark Nursery Grounds of the Gulf of Mexico and East Coast waters of the United States. American Fisheries Society Symposium 50, 153-164.

Harrie, A.C. 2002. Contaminants in sharks of the south Atlantic Bight: an assessment of pesticides and PCBs in shark liver. Unpublished M.S. Thesis, University of South Carolina.

Holstege, D.M., Scharberg, D.L., Tor, E.R., Hart, L.C., Galey, F.D., 1994. A rapid multiresidue screen for organophosphorus, organochlorine, and $N$-methylcarbamate insecticides in plant and animal tissues. Journal of AOAC International 77, 1263-1274.

Kannan, K., Nakata, H., Stafford, R., Masson, G.R., Tanabe, S., Giesy, J.P., 1998. Bioaccumulation and toxic potential of extremely hydrophobic polychlorinated biphenyl congeners in biota collected at a Superfund site contaminated with Aroclor 1268. Environmental Science and Technology 32, 1214-1221.

Long, E.R., Scott, G.I., Kucklick, J., Fulton, M., Thompson, B., Carr, R.S., Biedenbach, J., Scott, K.J., Thursby, G.B., Chandler, G.T., Anderson, J.W., Sloane, G.M. 1998. Magnitude and extent of sediment toxicity in selected estuaries of South Carolina and Georgia. NOAA Technical Memorandum NOS ORCA 128. Silver Spring, MD.

Maruya, K.A., Lee, R.F., 1998. Arochlor 1268 and toxaphene in fish from a southeastern US estuary. Environmental Science and Technology 32, 1069-1075.
Maruya, K.A., Walters, T.L., Manning, R.O., 2001. Residues of toxaphene in finfish and shellfish from Terry and Dupree Creeks, Georgia, U.S.A. Estuaries 24, 585-596.

National Marine Fisheries Service. 2003. Final amendment 1 to the Fishery Management Plan for Atlantic tunas, swordfish, and sharks. NOAA/NMFS, Silver Spring, MD.

Pulster, E.L., Smalling, K.L., Maruya, K.A., 2005. Polychlorinated biphenyls and toxaphene in preferred prey fish of coastal southeastern U.S. bottlenose dolphins (Tursiops truncatus). Environmental Toxicology and Chemistry 24, 3128-3136.

Schenck, F.J., Wagner, R., Hennessy, M.K., Okrasinski Jr., J.L., 1994. Screening procedure for organochlorine and organophosphorus pesticide residues in eggs using a solid-phase extraction cleanup and gas chromatographic detection. Journal of AOAC International 77, 10361040.

Schlenk, D., Sapozhnikova, Y., Cliff, G., 2005. Incidence of organochlorine pesticides in muscle and liver tissues of South African great white sharks Carcharodon carcharias. Marine Pollution Bulletin 50, 208211.

Serrano, R., Fernandez, M.A., Hernandez, L.M., Hernandez, M., Pascual, P., Rabanal, R.M., Gonzalez, M.J., 1997. Coplanar polychlorinated biphenyl congeners in shark livers from the North-Western African Atlantic Ocean. Bulletin of Environmental Contamination and Toxicology 58, 150-157.

Serrano, R., Fernandez, M., Rabanal, R., Hernandez, M., Gonzalez, M.J., 2000. Congener-specific determination of polychlorinated biphenyls in shark and grouper livers from the northwest African Atlantic Ocean. Archives of Environmental Contamination and Toxicology 38, 217-224.

Storelli, M.M., Ceci, E., Storelli, A., Marcotrigiano, G.O., 2003. Polychlorinated biphenyl, heavy metal and methylmercury residues in hammerhead sharks: contaminant status and assessment. Marine Pollution Bulletin 46, 1035-1039.

Storelli, M.M., Marcotrigiano, G.O., 2001. Persistent organochlorine residues and toxic evaluation of polychlorinated biphenyls in sharks from the Mediterranean Sea (Italy). Marine Pollution Bulletin 42, $1323-1329$.

Strid, A., Jörundsdóttir, H., Päpke, O., Svavarsson, J., Bergman, Å., 2007. Dioxins and PCBs in Greenland shark (Somniosus microcephalus) from the north-east Atlantic. Marine Pollution Bulletin 54, 1514-1522.

\title{
Trace metals and benthic macrofauna distributions in Camamu Bay, Brazil: Sediment quality prior oil and gas exploration
}

\author{
Vanessa Hatje ${ }^{\mathrm{a}, *}$, Francisco Barros ${ }^{\mathrm{b}}$, Wagner Magalhães ${ }^{\mathrm{b}}$, Valéria B. Riatto ${ }^{\mathrm{a}}$, \\ Fabiola N. Amorim ${ }^{\mathrm{c}}$, Maria Betânia Figueiredo ${ }^{\mathrm{b}}$, Saulo Spanó ${ }^{\mathrm{c}}$, Mauro Cirano ${ }^{\mathrm{c}}$ \\ a Departamento de Química Analítica, Instituto de Química, Universidade Federal da Bahia, Campus Ondina, 40170-290 Salvador-BA, Brazil \\ ${ }^{\mathrm{b}}$ Departamento Zoologia, Instituto de Biologia, Universidade Federal da Bahia, Campus Ondina, 40170-290 Salvador-BA, Brazil \\ ${ }^{c}$ Departamento de Física da Terra e do Meio Ambiente, Instituto de Física, Universidade Federal da Bahia, Campus Ondina, 40170-290 Salvador-BA, Brazil
}

Offshore oil and gas production in fragile ecosystems has been a subject of much concern and discussion. There

\footnotetext{
${ }^{*}$ Corresponding author. Tel./fax: +557132355166 .

E-mail address: vhatje@ufba.br (V. Hatje).
}

are various risks and potential consequences associated with petroleum exploration and related activities. Impacts of oil spills, dredging, drilling and ship movements on sediment composition and benthic assemblages are well 
documented (e.g. Gray et al., 1990; Chapman et al., 1991; Rezende et al., 2002; Albaigés et al., 2006).

In the past few years, there has been increasing attention directed toward the relative pristine Camamu Bay, Bahia, northeast Brazil in terms of offshore oil and gas reserves and tourism potential. The Bahia State has the second largest offshore oil field of Brazil, with a total reservoir of 424 millions of barrels. Recently, eighteen areas on the adjacent continental shelf of Camamu Bay, including six areas located in shallow waters, were offered for concession during international auctions (ANP, 2006). The petroleum industry has already started operations in the mentioned area.

Sediment investigations carried out in marine coastal areas around the world have demonstrated the importance of the spatial and temporal characterization of sediments composition and benthic macrofauna assemblages to evaluate and monitoring environmental impacts, especially in heavily populated and industrialized regions. Few studies have, however, been made on pristine areas. Here, contemporaneous trace metal and benthic assemblage data is presented for Camamu Bay, a nearly pristine area in the central coast of Bahia (Fig. 1).

Camamu Bay, an Environmental Protected Area, is a circular shaped, shallow bay, covering an area of approximately $384 \mathrm{~km}^{2}$. The catchment area can be divided into smaller hydrological units. In the northern section, there is the Serinhaém, a shallow estuarine system. The central part of the bay receives water from Igrapiúna, Pinare and Sorajó Rivers. It is a shallow zone, with average depths of $3 \mathrm{~m}$ and maximum depths of $7 \mathrm{~m}$, within river channels.
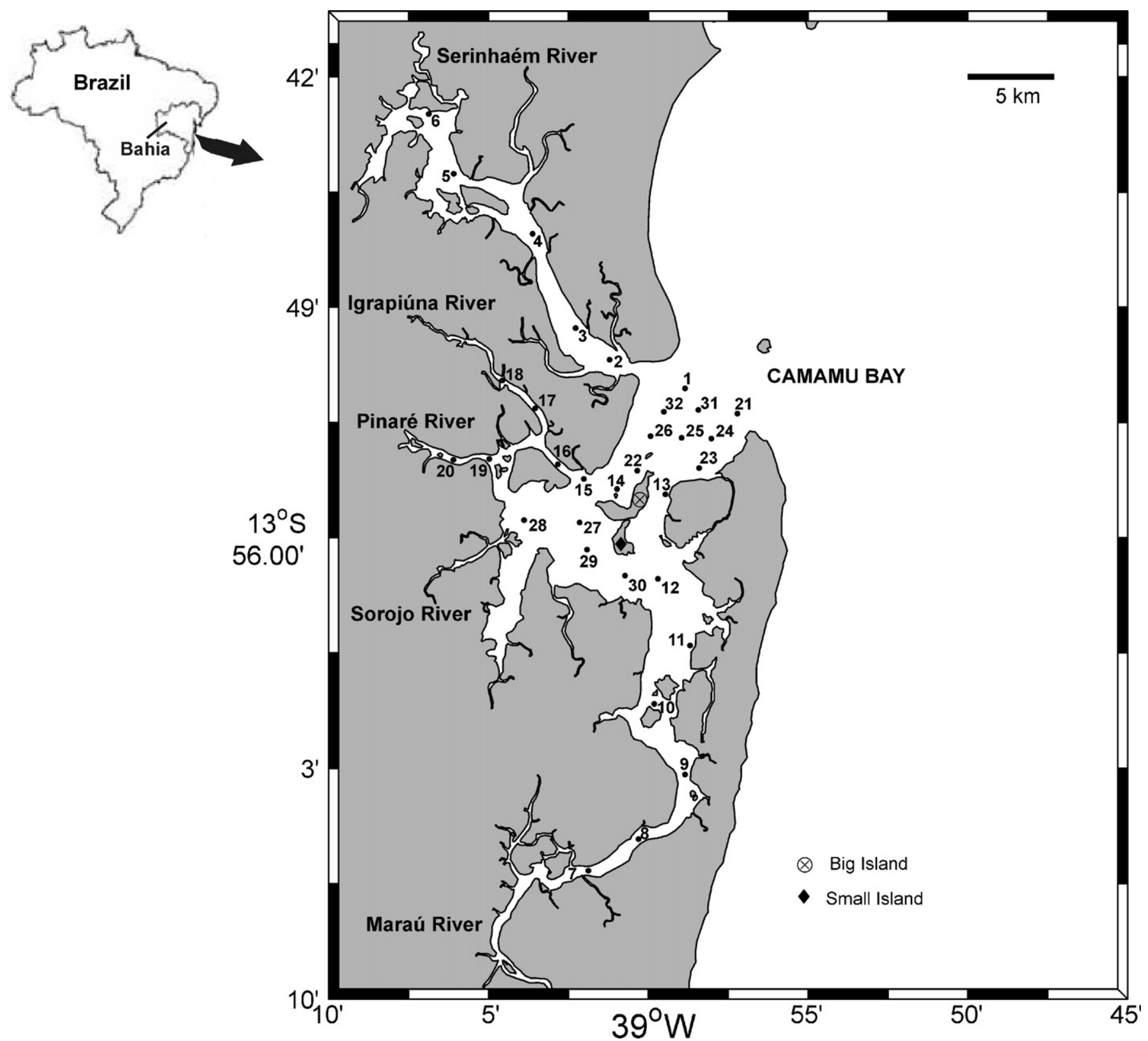

Fig. 1. Location of sampling sites in Camamu Bay, Bahia, Brazil. 
Table 1

Mean and standard deviation obtained for 4 replicates of the certified reference material MESS- 2 and detection limits ( $\mathrm{mg} \mathrm{kg}^{-1}$ )

\begin{tabular}{llll}
\hline Element & Certified & Measured & Detection limits \\
\hline $\mathrm{As}$ & $20.7 \pm 0.80$ & $8.22 \pm 0.3$ & 0.001 \\
$\mathrm{Ba}$ & - & $163 \pm 16$ & 0.002 \\
$\mathrm{Cd}$ & $0.24 \pm 0.01$ & $\mathrm{bd}$ & 0.001 \\
$\mathrm{Co}$ & $13.8 \pm 1.4$ & $5.10 \pm 0.4$ & 0.004 \\
$\mathrm{Cr}$ & $106 \pm 8$ & $4.44 \pm 0.4$ & 0.004 \\
$\mathrm{Cu}$ & $39.3 \pm 2$ & $17.1 \pm 0.7$ & 0.006 \\
$\mathrm{Fe}$ & $4.35 \pm 0.22$ & $0.98 \pm 0.03$ & 0.05 \\
$\mathrm{Mn}$ & $365 \pm 21$ & $185 \pm 7.2$ & 0.351 \\
$\mathrm{Ni}$ & $49.3 \pm 1.8$ & $11.4 \pm 0.6$ & 0.008 \\
$\mathrm{~Pb}$ & $21.9 \pm 1.2$ & $13.6 \pm 0.7$ & 0.017 \\
$\mathrm{~V}$ & $252 \pm 10$ & $23.8 \pm 1.3$ & 0.002 \\
$\mathrm{Zn}$ & $172 \pm 16$ & $60.3 \pm 3.4$ & 0.002 \\
\hline $\mathrm{Concentration}$
\end{tabular}

Concentrations in $\mathrm{mg} \mathrm{kg}^{-1}$ with the exception of $\mathrm{Fe}(\%)$.

bd $=$ below detection.

The Maraú system, located in the southern part of the Bay, has an area of $120 \mathrm{~km}^{2}$. Maximum depths $(37 \mathrm{~m})$ are found in the channel that extents to the main entrance of the Bay with approximately $6.4 \mathrm{~km}$ wide. Most of the studied areas in the tributaries and a great part of the Bay are largely estuarine in nature and present large mangrove areas. The circulation inside the Bay is supra-inertially forced, and tidally driven (Amorim, 2005). Tides are semi-diurnal with a maximum tidal range of $2.7 \mathrm{~m}$ during spring tides and current velocities varying between 0.6 and $1.2 \mathrm{~m} \mathrm{~s}^{-1}$ (Amorim, 2005). Salinities in the Camamu Bay entrance vary between 35.6 and 37.5, with weak to moderate vertical stratification (Amorim, 2005). The Bay acts as a refuge, feeding and nursery area for many species, which will be threatened by accidents during operation of oil and gas fields located only a couple of kilometers seaward. Numerical simulations with oil spills performed by Amorim (2005) have shown that the Bay could be affected within periods of less than one day, in the worst scenarios. Studies have focused on the potential of mining barite at two islands inside the Bay, but no extensive research has been carried out on trace metals and benthic assemblages. To address this, the aims of this present study were to: (1) characterize the distribution and concentration of trace metals; and (2) characterize the structure of the benthic macrofauna

Table 2

Trace metal concentrations $\left(\mathrm{mg} \mathrm{kg}^{-1}\right)$ and grain size $(\%)$ of Camamu Bay sediments

\begin{tabular}{|c|c|c|c|c|c|c|c|c|c|c|c|c|c|c|c|c|}
\hline \multirow[b]{2}{*}{ Stations } & \multicolumn{12}{|c|}{ Trace elements $(\mathrm{mg} / \mathrm{kg})$} & \multicolumn{4}{|c|}{ Grain size $(\%)$} \\
\hline & As & $\mathrm{Ba}$ & $\mathrm{Cd}$ & Co & $\mathrm{Cr}$ & $\mathrm{Cu}$ & $\mathrm{Fe}$ & $\mathrm{Mn}$ & $\mathrm{Ni}$ & $\mathrm{Pb}$ & $\mathrm{V}$ & $\mathrm{Zn}$ & Gravel & Sand & Silt & Clay \\
\hline 1 & 1.67 & 28.1 & bd & 0.77 & 1.03 & 2.50 & 1.621 & 34.9 & 1.86 & 1.77 & 3.60 & 7.38 & 0.53 & 99.5 & 0.00 & 0.00 \\
\hline 2 & 0.53 & bd & bd & bd & 0.13 & 1.04 & 149 & 7.42 & 0.16 & bd & 0.26 & bd & 16.5 & 55.5 & 18.1 & 9.89 \\
\hline 3 & 2.39 & 0.80 & bd & 0.79 & 1.02 & bd & 2.540 & 38.1 & 0.38 & 0.94 & 1.22 & 5.85 & 3.28 & 92.8 & 3.90 & 0.00 \\
\hline 4 & 1.04 & 0.33 & bd & 0.93 & 0.85 & bd & 2.064 & 69.1 & 0.42 & 0.58 & 1.72 & 5.44 & 0.00 & 84.6 & 7.14 & 8.29 \\
\hline 5 & 5.60 & 7.05 & bd & 6.04 & 14.1 & 0.42 & 22.900 & 170 & 7.00 & 6.85 & 15.0 & 77.5 & 0.66 & 68.0 & 14.9 & 16.5 \\
\hline 6 & 3.56 & 2.19 & $\mathrm{bd}$ & 5.94 & 9.03 & 0.56 & 14.570 & 95.3 & 4.88 & 4.39 & 13.8 & 68.1 & 0.02 & 79.9 & 11.1 & 8.95 \\
\hline 7 & 0.40 & 0.84 & bd & bd & bd & bd & 340 & 3.60 & bd & 0.26 & 0.76 & 0.44 & 3.33 & 93.7 & 2.97 & 0.00 \\
\hline 8 & nd & nd & nd & nd & nd & nd & nd & nd & nd & nd & nd & nd & 0.08 & 99.9 & 0.00 & 0.00 \\
\hline 9 & 2.25 & 17.9 & bd & 0.96 & 2.00 & 0.22 & 1.894 & 30.6 & 0.94 & 2.05 & 6.07 & 6.52 & 0.00 & 99.4 & 0.58 & 0.00 \\
\hline 10 & 3.65 & 133 & bd & 2.19 & 6.95 & 1.48 & 5.206 & 86.4 & 2.85 & 10.2 & 15.7 & 16.1 & 0.06 & 66.6 & 16.2 & 17.2 \\
\hline 11 & 7.96 & 112 & bd & 6.03 & 13.4 & 2.02 & 18.000 & 295 & 6.49 & 16.9 & 21.9 & 38.9 & 28.2 & 56.8 & 9.60 & 5.47 \\
\hline 12 & 2.73 & 33.1 & bd & 0.43 & 1.91 & 0.31 & 1.826 & 48.5 & 0.46 & 2.09 & 2.64 & 2.78 & 1.61 & 70.2 & 14.4 & 13.8 \\
\hline 13 & 2.46 & 121 & bd & 0.55 & 0.82 & 0.52 & 782 & 81.4 & bd & 10.4 & 2.53 & 1.57 & 0.94 & 99.1 & 0.00 & 0.00 \\
\hline 14 & 4.17 & 41.0 & 0.17 & 1.03 & 4.27 & 0.91 & 3.455 & 81.9 & 1.01 & 4.68 & 6.43 & 7.43 & 12.1 & 74.3 & 6.22 & 7.41 \\
\hline 15 & 1.85 & 4.08 & 0.02 & 0.18 & 0.73 & bd & 1.246 & 15.5 & 0.13 & 1.14 & 0.61 & 1.58 & 1.45 & 97.6 & 0.92 & 0.00 \\
\hline 16 & 1.33 & 15.6 & 0.04 & 0.56 & 1.52 & 0.13 & 1.787 & 29.0 & 0.54 & 1.55 & 3.81 & 3.47 & 12.0 & 84.4 & 3.56 & 0.00 \\
\hline 17 & 0.80 & 2.14 & 0.04 & 0.69 & 0.99 & bd & 1.598 & 40.5 & 0.30 & 0.43 & 0.53 & 2.97 & 0.00 & 97.2 & 2.82 & 0.00 \\
\hline 18 & 0.55 & 8.74 & 0.04 & 0.33 & 1.40 & bd & 1.662 & 10.2 & 0.47 & 1.62 & 3.48 & 3.89 & 0.00 & 99.6 & 0.45 & 0.00 \\
\hline 19 & 9.13 & 20.7 & 0.46 & 1.48 & 7.04 & 0.29 & 6.631 & 41.9 & 3.03 & 8.56 & 23.3 & 18.1 & 30.5 & 65.2 & 4.33 & 0.00 \\
\hline 20 & 2.29 & 8.26 & 0.47 & 1.14 & 3.87 & bd & 7.238 & 46.8 & 1.58 & 1.92 & 4.38 & 15.7 & 0.62 & 99.0 & 0.41 & 0.00 \\
\hline 21 & 3.41 & 2.70 & 0.01 & 0.43 & 1.53 & 1.27 & 1.186 & 55.9 & 0.64 & 0.93 & 3.42 & 1.96 & 12.2 & 87.8 & 0.00 & 0.00 \\
\hline 22 & 1.15 & 0.65 & $\mathrm{bd}$ & 0.09 & 0.62 & 0.33 & 276 & 8.21 & 0.08 & 0.45 & $\mathrm{bd}$ & 0.59 & 0.07 & 99.9 & 0.00 & 0.00 \\
\hline 23 & 1.81 & 1.06 & bd & 0.10 & 1.55 & 0.74 & 465 & 16.1 & 0.17 & 0.48 & 0.51 & 0.97 & 0.00 & 100 & 0.00 & 0.00 \\
\hline 24 & 1.44 & 0.26 & bd & 0.10 & 0.83 & 0.66 & 188 & 8.38 & 0.08 & 0.53 & 0.27 & 0.54 & 0.22 & 99.8 & 0.00 & 0.00 \\
\hline 25 & 3.45 & 55.8 & 0.05 & 1.08 & 4.17 & 1.89 & 3.328 & 62.7 & 1.24 & 4.24 & 6.84 & 8.24 & 5.79 & 80.1 & 8.02 & 6.11 \\
\hline 26 & 0.29 & 0.35 & bd & 0.08 & 0.64 & 0.38 & 258 & 6.16 & 0.09 & 0.30 & 0.12 & 0.72 & - & - & - & - \\
\hline 27 & 6.92 & 328 & 0.12 & 2.74 & 10.4 & 1.71 & 8.233 & 141 & 3.81 & 11.6 & 13.7 & 23.3 & 1.00 & 41.3 & 31.8 & 25.9 \\
\hline 28 & 4.15 & 139 & 0.10 & 1.64 & 8.36 & 1.11 & 6.179 & 63.7 & 2.36 & 6.90 & 8.62 & 19.42 & - & - & - & - \\
\hline 29 & 0.24 & 0.43 & bd & 0.12 & 0.11 & bd & 197 & 1.52 & $\mathrm{bd}$ & $\mathrm{bd}$ & 0.22 & 0.66 & 1.88 & 40.1 & 34.5 & 23.6 \\
\hline 30 & 10.9 & 157 & 0.65 & 9.92 & 30.0 & 1.33 & 23.325 & 518 & 11.2 & 24.8 & 23.4 & 68.4 & 3.08 & 52.9 & 24.7 & 19.3 \\
\hline 31 & 1.36 & 0.32 & $\mathrm{bd}$ & 0.42 & 0.96 & 0.24 & 896 & 53.8 & 0.44 & 0.58 & 1.23 & 1.31 & 0.78 & 99.2 & 0.00 & 0.00 \\
\hline 32 & 2.46 & 30.3 & 0.02 & 0.59 & 2.48 & 0.74 & 1663 & 57.5 & 0.82 & 2.80 & 4.40 & 3.80 & 0.75 & 98.6 & 0.62 & 0.00 \\
\hline Maximum & 10.9 & 328 & 0.65 & 9.92 & 30.0 & 2.50 & 23.325 & 518 & 11.2 & 24.8 & 23.4 & 77.5 & 30.5 & 100 & 34.5 & 25.9 \\
\hline Minimum & 0.24 & 0.26 & 0.01 & 0.08 & 0.11 & 0.13 & 149 & 1.5 & 0.08 & 0.26 & 0.12 & 0.44 & 0.00 & 40.1 & 0.00 & 0.00 \\
\hline
\end{tabular}

nd $=$ not determined. bd $=$ below detection 
assemblages in Camamu Bay before the beginning of oil and gas exploration.

Surface sediment samples were collected, using a Van Veen grab, in 32 stations across the Bay and in the main tributaries in July 2005 (Fig. 1). Following collection, samples were transferred to a pre-cleaned LDPE container and kept frozen until analysis. All bottles and materials used for the collection and analysis were cleaned and immersed for at least $24 \mathrm{~h}$ in a detergent solution and for a further $48 \mathrm{~h}$ in $10 \% \mathrm{HNO}_{3}$ solution. They were then rinsed with ultra pure water, dried on a clean covered bench and stored in zip-lock bags before use. Sediment samples were divided into two parts. The first was use to characterize particlesize distribution, by wet sieving, and the second for chemical analyses. An extraction of trace metals was the carried out using $20 \mathrm{ml}$ of $1.0 \mathrm{M} \mathrm{HCl}$ shaking for $12 \mathrm{~h}$ at room temperature. The latter extraction is reported to closely correlate with biological availability of trace metals (Bryan and Langston, 1992). Sediment samples were extracted in triplicates. Trace metals (As, Ba, Co, Cd, Cr, $\mathrm{Cu}, \mathrm{Fe}$, $\mathrm{Mn}, \mathrm{Ni}, \mathrm{Pb}, \mathrm{V}$ and $\mathrm{Zn}$ ), were determined by ICP OES (Varian, VISTA-PRO). Details of trace metal determinations can be found elsewhere (e.g. Hatje et al., 2006a). Blanks were included in each batch of analysis. The precision and accuracy of the analytical technique for each batch of samples were assessed by analysis of a Certified Reference Material, MESS-2 (National Research Council of Canada). The average and standard deviation of the results of MESS-2 analyses are given in Table 1. Results indicated good analytical precision, but incomplete digestion (4.6$62 \%$ ), which was not unexpected since the extraction procedure did not include hydrofluoric acid.

In order to examine the structure of the macrofaunal assemblages, two sites, about $50 \mathrm{~m}$ apart, were randomly sampled at 20 stations (\#1-\#20). At each site, 3 replicate Van Veen grabs were collected, totaling $1.8 \mathrm{~m}^{2}$ of sampled area per station. Samples of macrofauna were sieved with a $0.5 \mathrm{~mm}$ mesh, preserved in $70 \%$ ethanol and maintained in a freezer for further sorting. In the laboratory, animals were counted and identified to family or morphotype. This taxonomic resolution was adequate because species level is often not necessary for the detection of spatial patterns of benthic macrofaunal assemblages (e.g. Barros et al., 2001; Barros et al., 2004).
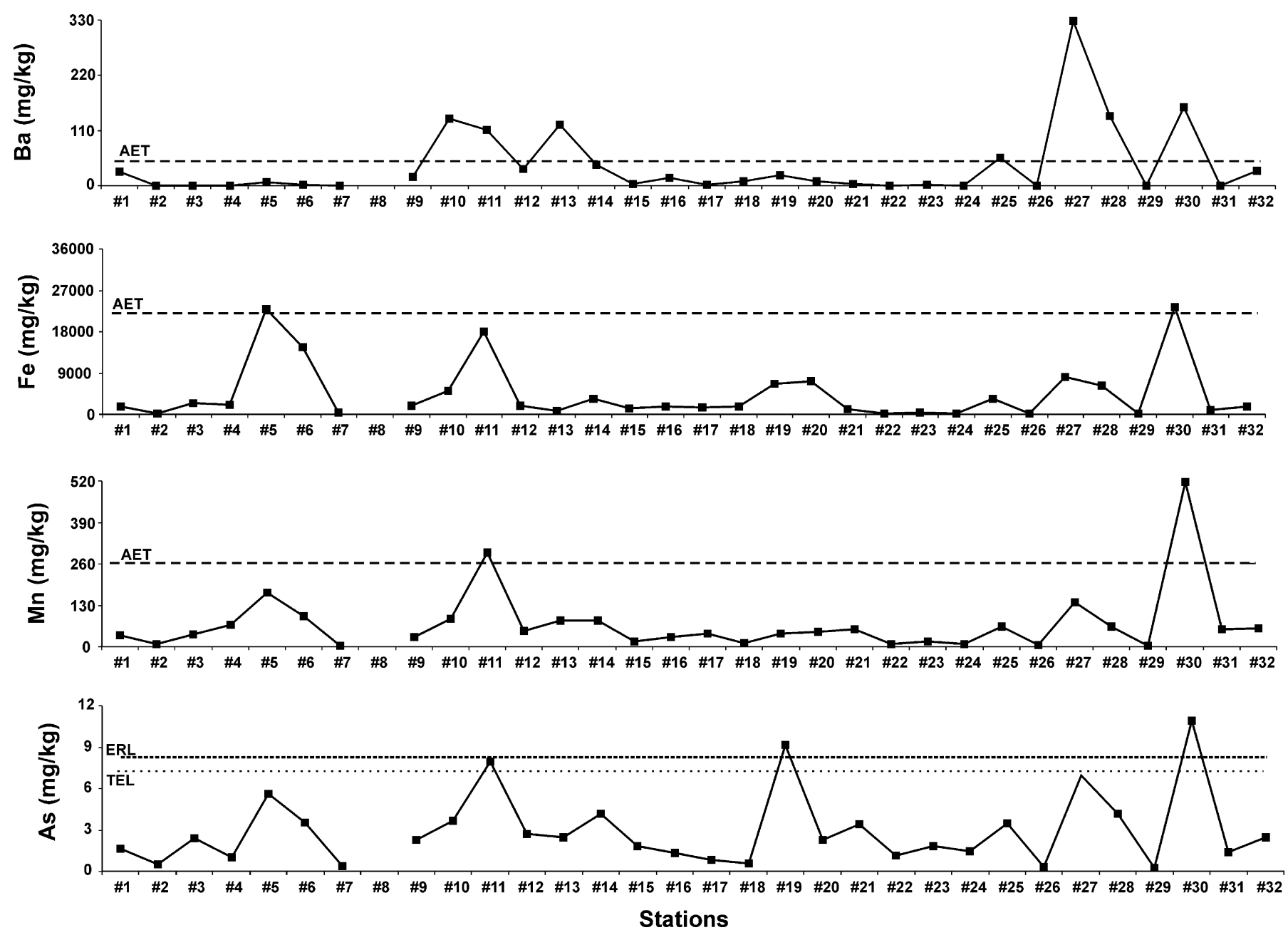

Fig. 2. Distributions of Ba, Fe, Mn and As in sediments of Camamu Bay. Threshold effects level (TEL), effects range-low (ERL) and apparent effects threshold (AET) levels are indicated. 
Non-metric multidimensional scaling (nMDS), based on Bray-Curtis dissimilarities of the fourth-root transformed macrofauna data was used to investigate the spatial patterns of macrofauna. In this analysis, replicates of each sites were pooled $(n=6)$. The relationships between multivariate patterns of environmental variables and macrofaunal assemblage structure were examined using the BIOENV procedure (Clarke and Ainsworth, 1993; Clarke and Warwick, 1994).

Grain size analysis (Table 2) indicated that sediments are generally coarse-grained. For the majority of the analyzed samples, sand represented more than $80 \%$ of sediments. The finer-grained, high surface area particles, such as silt and clay, were found mainly at Serinhaém (\#2, \#4-\#6), at the mouth of the Maraú River (\#10-\#12) and at the central part of the Bay (\#27-\#30). As a consequence these stations are more likely to have higher metal contents, than sandier, low surface area sediments located at the entrance of Camamu Bay.

A summary of trace metal concentrations in Camamu Bay sediments is given in Table 2. Iron, $\mathrm{Mn}$ and $\mathrm{Ba}$ had the highest concentrations in Camamu sediments of all the studied metals. The maximum concentrations for $\mathrm{Mn}$ $(141-518 \mathrm{mg} / \mathrm{kg})$ and $\mathrm{Fe}(1.46-2.33 \%)$ were found at the mouth of the Maraú River (\#11), around the small and big islands (\#27 and \#30) and upstream Serinhaém River (\#5-\#6). The maximum concentrations of $\mathrm{Ba}$ (112$328 \mathrm{mg} / \mathrm{kg}$ ) were also located around the small and big islands (\#13, \#27 and \#30) and at the mouth of the Maraú River (\#10 and \#11). In general, $\mathrm{Co}, \mathrm{Cr}, \mathrm{Ni}, \mathrm{Pb}, \mathrm{V}$ and $\mathrm{Zn}$ followed distribution patterns of $\mathrm{Fe}$ and $\mathrm{Mn}$. Moreover, elements such as As, $\mathrm{Cd}$ and $\mathrm{V}$ were also found in relatively high concentrations at Pinaré River (\#19 and \#20). Compared to other metals, $\mathrm{Cu}$ concentrations were lower and did not show a clear spatial pattern.

All studied elements, with the exception of $\mathrm{Ba}$ and $\mathrm{Cu}$ were highly correlated $(p<0.05)$ to Fe and Mn. The correlations of metals with $\mathrm{Mn}$ and $\mathrm{Fe}$ suggest that metals were strongly associated with the $\mathrm{Fe}$ and $\mathrm{Mn}$ oxyhydroxides phase (all samples presented oxic conditions), and/or they have a common source. Trace metals showed low, but significant, correlations with silt and clay $(r<0.5, p<0.05)$. This result suggests that the distribution of metals at Camamu Bay is not only linked to deposit or accumulation zones, but it is also a function of point sources and the transport routes of contaminants. In contrast, Oliveira (2000) found that trace metals $(\mathrm{Cr}, \mathrm{Pb}, \mathrm{Zn}, \mathrm{Mn}, \mathrm{Al}$ and $\mathrm{Fe}$ ) were strongly correlated with fine particles and organic matter in Camamu Bay sediments. Oliveira (2000) samples were, however, collected in intertidal mangroves areas, rich in organic matter, where sediments were predominantly composed by silt and clay, whereas samples in the present study were mainly coarse grained.

A comparison of the trace metals that presented the highest concentrations in Camamu Bay to the NOAA (1999) Threshold Effects Level (TEL), Effects Range-Low (ERL) and Apparent Effects Threshold (AET) levels is

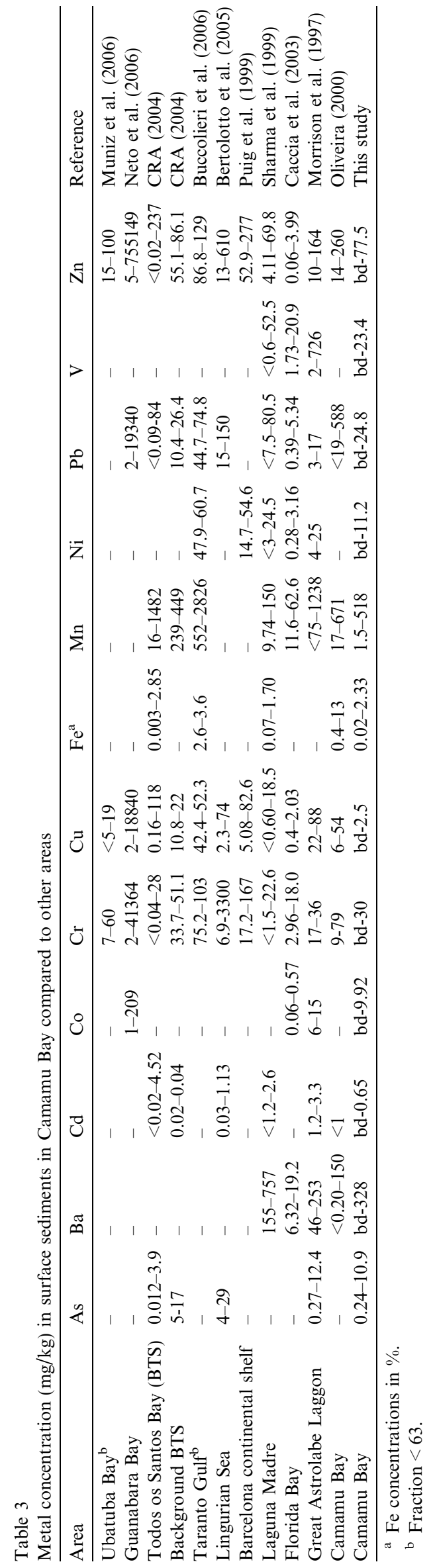


presented in Fig. 2. Barium concentrations in almost 30\% of the samples showed concentrations close to or above AET levels. The latter represents the concentration above which adverse biological impacts would always be expected. Sediment samples that presented concentrations above AET levels were found nearby small and big islands, where there is a barite reservoir estimated at 25 millions of tons (Oliveira, 2000). Mining of this area started in 1940, but as a major part of the reservoir is submersed and most of it has not been explored yet. Analysis of barite samples from small and big islands (Campos, 1984) showed high concentrations of $\mathrm{Ba}, \mathrm{Pb}$ and $\mathrm{Zn}$, i.e. $39-58 \%, 31-$ $5000 \mathrm{mg} / \mathrm{kg}$ and $54-4950 \mathrm{mg} / \mathrm{kg}$, respectively. From the studied elements only $\mathrm{Pb}$ showed a high correlation $(r=0.73 ; P<0.05)$ with $\mathrm{Ba}$, suggesting that, at least in the vicinity of small and big island, the barite mining is the main source of these elements. Nevertheless, $\mathrm{Pb}$ concentrations were below Threshold Effects Level (TEL; NOAA, 1999).

Manganese and $\mathrm{Fe}$ also were found in concentrations close to or above AET in the vicinity of the small and big island, reflecting the mining activity. Moreover, $\mathrm{Fe}$ also exceeded AET levels upstream Serinhaém River. The enrichment of $\mathrm{Fe}$, as well as relatively high concentrations of $\mathrm{As}, \mathrm{Co}, \mathrm{Cr}, \mathrm{Mn}, \mathrm{Ni}, \mathrm{Pb}, \mathrm{V}$ and $\mathrm{Zn}$, in the upper Serinhaém signal the influence of the near by urbanized catchment at Ituberá. This area has approximately 20,800 inhabitants and active rubber and sugar cane industries. Lack of sewage treatment in this area, means that urban and industrial runoff probably influenced metal distributions in the sediments of upper Serinhaém River.

The relatively high levels of $\mathrm{Ba}, \mathrm{Fe}, \mathrm{Mn}$, among other metals, in Maraú River mouth area may be associated with the residual flux of the main channel of the Camamu Bay. This flux, directed towards Maraú channel (Amorim, 2005), could be redistributing contaminated sediments from the east side of the small and big islands to the Maraú River, during flood tide. During the ebb tide this contaminated sediment may be carried to the central part of the bay (west of small and big islands), which is very shallow and has low circulation.

Arsenic presented, unexpected, high concentrations in various stations along the Bay, similar to $\mathrm{Ba}, \mathrm{Fe}$ and $\mathrm{Mn}$ distributions, suggesting that mining is also an important source for As. Concentrations of As (Fig. 2) above Effects Range Median (ERL; NOAA, 1999), which represents the value at which toxicity may begin to be observed in sensitive species, were also observed at Pinaré River. This region, as well as all the central part of the Bay, has several
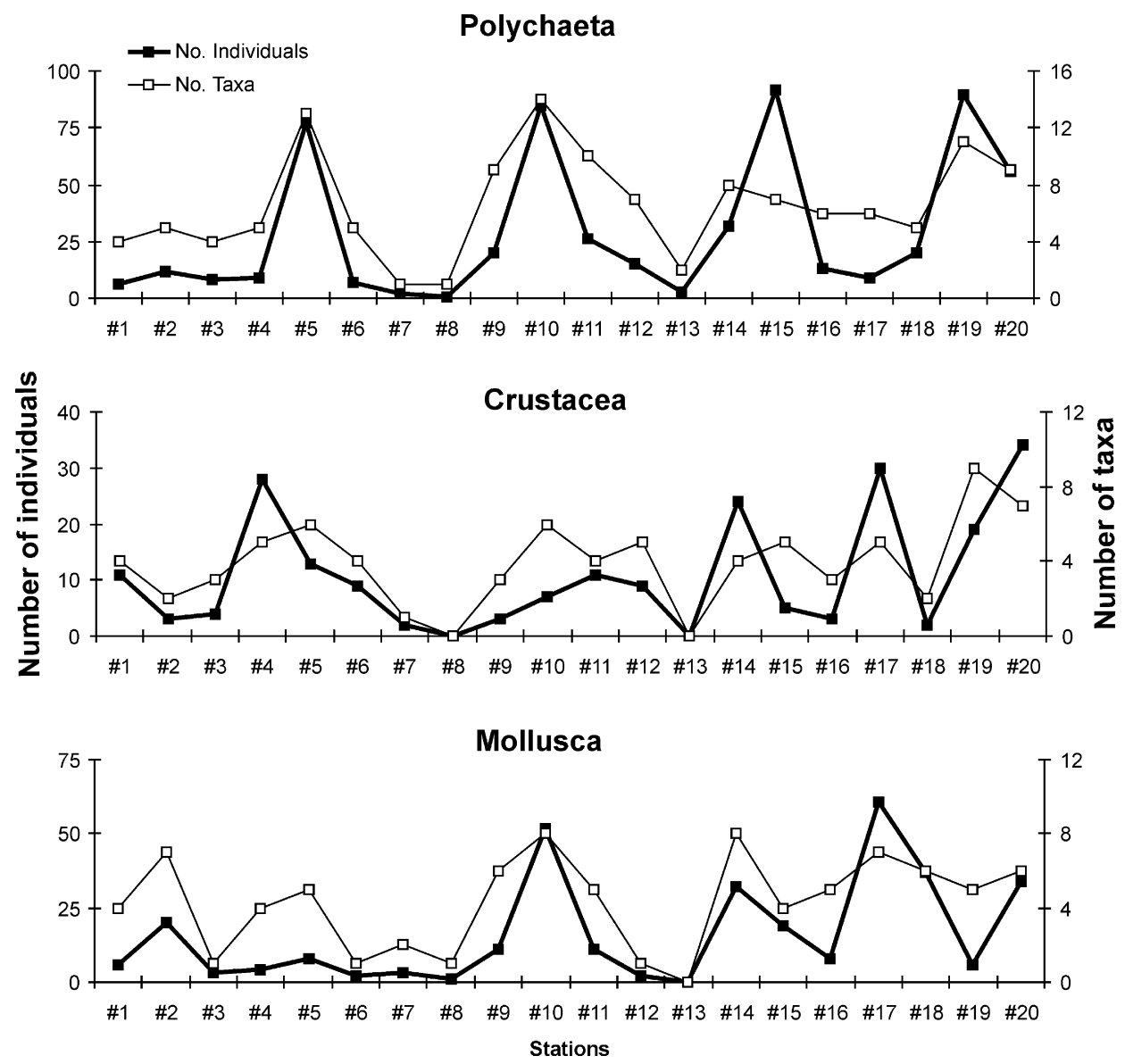

Fig. 3. Number of individuals and taxa of Polychaeta, Crustacea and Mollusca at 20 stations sampled at Camamu Bay. 
small timber shipyards that may be using chromated copper arsenate (CCA) as wood preservative, resulting in high As levels in sediments, although this hypothesis needs to be further investigated.

Minimum concentrations of all metals were found in the lower Serinhaém River, and at the entrance of the Bay. These zones are located near the mouth of Camamu Bay, where residency time of the waters maybe short and waters of the Bay mix with Atlantic waters that contain low metal concentration (ENSR, 2004).

A comparison of trace metals concentrations with other areas is shown in Table 3. From the studied elements, only $\mathrm{Cu}$ and $\mathrm{V}$ presented concentrations in the same range as pristine areas, such as Florida Bay (Caccia et al., 2003). Compared to background levels of trace metals in Todos os Santos Bay (CRA, 2004), around $100 \mathrm{~km}$ north of the study area, the concentrations of $\mathrm{As}, \mathrm{Cr}, \mathrm{Cu}, \mathrm{Pb}$ and $\mathrm{Zn}$ are in the range of natural metal concentrations. Nevertheless, $\mathrm{Mn}$ and $\mathrm{Cd}$ concentrations exceeded background values. Compared to other contaminated coastal areas, the levels obtained in this study were, in general, much lower.

In total of 1433 benthic invertebrates, distributed in 115 taxa, were sampled. The mean number of individuals and taxa per station were 54 (s.e. \pm 12.1 ) and 8.4 (s.e. \pm 1.9 ), respectively. The total abundance at each station varied betwen 3 (\#8) to 153 individuals (\#10 and \#17). The most abundant taxa was an anfioxus from the genus Branchios- toma, which accounted for $15 \%$ of the total abundance. This was followed by polychaetes from the families Magelonidae $(7.5 \%)$ and Nereididae (7\%). The most diverse stations showed 25-33 different taxa (\#5, \#10, \#11, \#14 and \#19).

The most abundant and diverse taxonomic groups were Mollusca (320 individuals; 36 taxa), Polychaeta (583 individuals; 35 taxa) and Crustacea (217 individuals; 22 taxa). Polychaetes and Crustaceans showed relatively high diversity and abundances at stations located at the upper Serinhaém River (\#4 and \#5), mouth of Maraú River (\#9-\#11) and at Pinaré River (\#19-\#20) (Fig. 3). High abundance and diversity of molluscs were also observed at Maraú River (\#10), Igrapiúna River (\#17-\#18) and at one station close to the big island (\#14).

The non-metric multidimensional scaling (nMDS) showed that the structure of the benthic macrofaunal assemblages were quite dissimilar at stations \#6-\#8 and \#13 (Fig. 4). Assemblages were less diverse and abundant at these stations than at other stations. It is likely that benthic macrofauna structure was negatively influenced by the high levels of Ba (above AET) at station \#13. Furthermore, it could be argued that the high concentrations of $\mathrm{Mn}$ and Fe found upstream Serinhaém River might be affecting the structure of the benthic assemblages. However, geochemical data alone cannot explain the structural changes in benthic assemblages at station \#7, and, unfortunately, there is no geochemical data for station \#8. Considering the
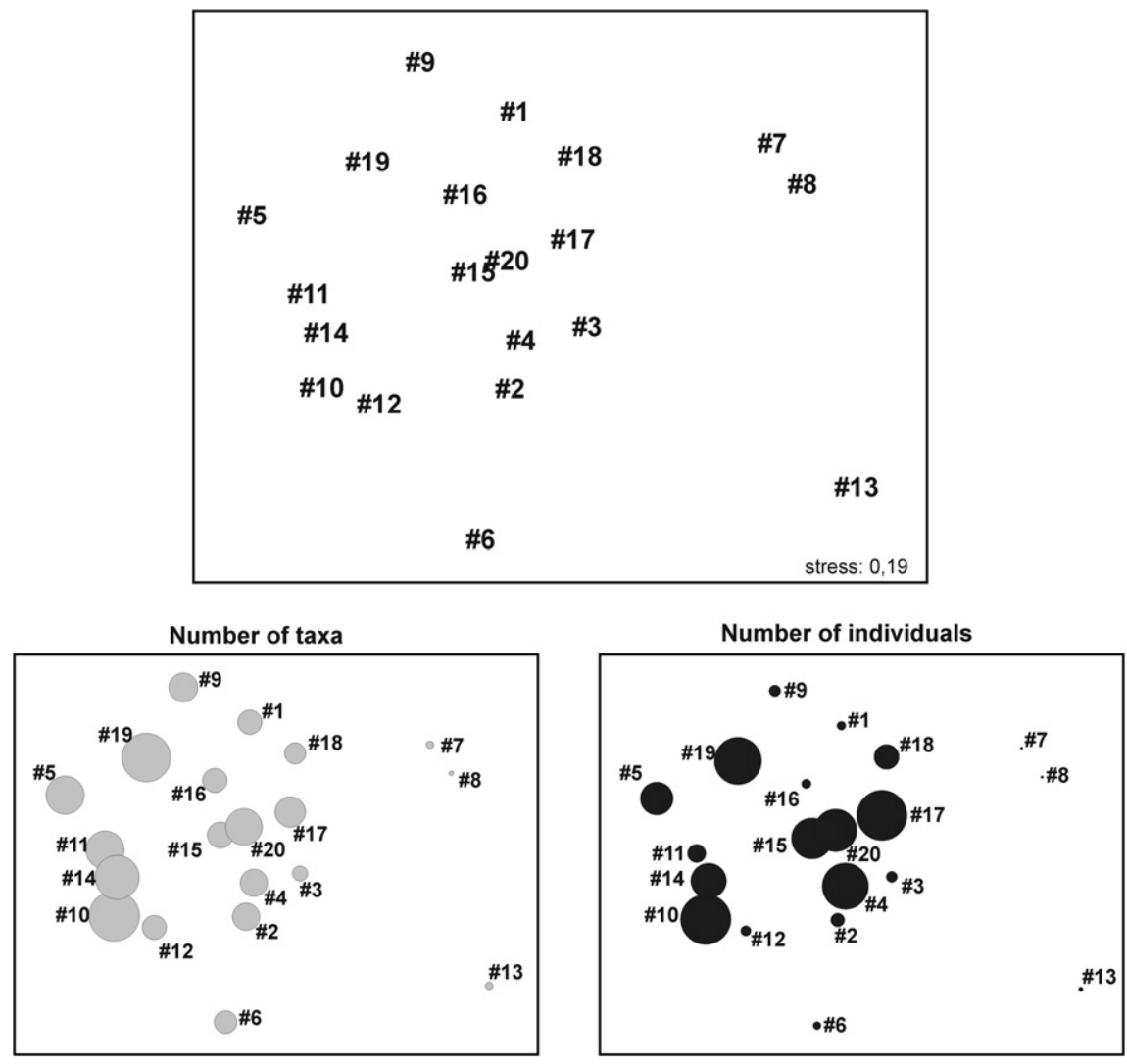

Fig. 4. Non-metric multidimensional scaling (nMDS) of the benthic macrofauna collected at Camamu Bay. Bubbles are representing values of number of different taxa, number of individuals at each station. 
biological data, permutations tests (BIOENV) indicated weak and not significant correlations $(\rho<0.5, p>0.05)$ with the environmental data. Moreover, the few stations with moderately high metal concentrations showed relatively high values of macrofauna abundance and taxonomic richness (e.g. \#5, \#10, \#11, \#19). A clear influence of trace metals concentrations in the structure of the benthic macrofauna in Camamu Bay could not be detected, as it was the case for other estuarine systems of Bahia, Brazil (e.g. Hatje et al., 2006b; CRA, 2004).

This study characterized the spatial distribution of trace metals and benthic macrofaunal assemblages on surface sediments collected across Camamu Bay prior to commencement of near by petroleum industries. Based on metal concentrations and benthic macrofauna, the Camamu Bay can be considered a relatively low impacted area when compared to background values and to most regional and worldwide coastal systems. Moreover, the obtained results illustrated the importance of multiples lines of evidence including benthos and sediment chemistry to evaluate health of soft-sediment habitats.

\section{Acknowledgement}

The authors are grateful to CNPq for financial support and to B. Kelaher for proofreading this manuscript.

\section{References}

Albaigés, J., Morales-Nin, B., Vilas, F., 2006. The prestige oil spill: a scientific response. Marine Pollution Bulletin 53, 205-207.

Amorim, F.N., 2005. Caracterização oceanográfica da Baía de Camamu e adjacências e mapeamento das áreas de risco a derrames de óleo. Universidade Federal da Bahia, Bahia, Brazil, Master dissertation, p. 191.

ANP, 2006. Anuário Estatístico, 2006. Agência Nacional do Petróleo. Ministério de Minas e Energia, http:www.brasil-rounds.gov.br/conheca/anuario_2006.asp.

Barros, F., Underwood, A.J., Lindegarth, M., 2001. The influence of rocky reefs on structure of benthic macrofauna in nearby soft sediments. Estuarine, Coastal and Shelf Science 52, 191-199.

Barros, F., Underwood, A.J., Archambault, P., 2004. The influence of troughs and crests of ripple marks on the structure of subtidal benthic assemblages around rocky reefs. Estuarine Coastal and Shelf Science 60, 781-790.

Bertolotto, R.M., Tortarolo, B., Frignani, F.M., Bellucci, L.G., Albanese, S., Cuneo, C., Alvarado-Aguilar, D., Picca, M.R., Gollo, E., 2005. Heavy metals in superficial coastal sediments of the Ligurian Sea. Marine Pollution 50, 351-359.

Bryan, G.W., Langston, W.J., 1992. Bioavailability, accumulation and effects of heavy metals in sediments with special reference to United Kingdom estuaries, a review. Environmental Pollution 76, 89-131.

Buccolieri, A., Buccolieri, G., Cardellicchio, N., Dell'Atti, A., Di Leo, A., Maci, A., 2006. Heavy metals in marine sediments of Taranto Gulf (Ionian Sea, Southern Italy). Marine Chemistry 99, 227-235.

0025-326X/\$ - see front matter (c) 2007 Elsevier Ltd. All rights reserved. doi:10.1016/j.marpolbul.2007.10.029
Caccia, V.G., Millero, F.J., Palanques, A., 2003. The distribution of trace metals in Florida Bay sediments. Marine Pollution Bulletin 46, 1420 1433.

Campos, E.G., 1984. Gênese e controle do depósito de barita de CamamuBa. Universidade Federal de Brasília, Brasília, Brazil, Master dissertation, p. 131.

Chapman, P.M., Power, E.A., Dexter, R.N., Andersen, H.B., 1991 Evaluation of effects associated with an oil platform, using the sediment quality triad. Environmental Toxicology and Chemistry 10, 407-424.

Clarke, K.R., Ainsworth, M., 1993. A method of linking multivariate community structure to environmental variables. Marine Ecology Progress Series 92, 205-219.

Clarke, K.R., Warwick, R.M., 1994. Change in Marine Communities: An Approach to Statistical Analysis and Interpretation. Natural Environment Research Council/Plymouth Marine Laboratory, UK, Plymouth.

CRA, 2004. Diagnóstico ambiental do grau de contaminação da Baía de Todos os Santos por metais pesados e hidrocarbonetos. CRA, Salvador.

ENSR/Elpaso, 2004. Diagnóstico Ambiental da Bacia de CamamuAlmada. Sedimento Marinho. Campanha verão de 2004. ENSR International, Rio de Janeiro.

Gray, J.S., Clarke, K.R., Warwick, R.M., Hobbs, G., 1990. Detection of initial effects of pollution on marine benthos: an example from the Ekofisk and Eldfisk oilfields, North Sea. Marine Ecology Progress Series 66, 285-299.

Hatje, V., Santos, D.S.S., Korn, M.G., 2006a. Preparation of an estuarine sediment quality control material for the determination of trace metals. Journal of Brazilian Chemical Society 17, 357-363.

Hatje, V., Barros, F., Figueiredo, D.G., Santos, V.L.C.S., Peso-Aguiar, M.C., 2006b. Trace metal contamination and benthic assemblages in Subaé estuarine system, Brazil. Marine Pollution Bulletin 52, 969-987.

Morrison, R.J., Gangaiya, P., Naqasima, M.R., Naidu, R., 1997. Trace metal studies in the Great Astrolabe Lagoon, Fiji, a pristine marine environment. Marine Pollution Bulletin 34, 353-356.

Muniz, P., Pires-Vanin, A.M.S., Martins, C.C., Montone, R.C., Bícego, M.C., 2006. Trace metals and organic compounds in the benthic environment of a subtropical embayment (Ubatuba Bay, Brazil). Marine Pollution Bulletin 52, 1090-1117.

Neto, J.A.B., Gingele, F.X., Leipe, T., Brehme, I., 2006. Spatial distribution of heavy metals in superficial sediments from Guanabara Bay, Rio de Janeiro, Brazil. Environmental Geology 46, 1051-1063.

NOAA, 1999. Screening Quick Reference Tables, NOAA HAZMAT Report 99-1, Coastal Protection and Restoration Division. National Oceanic and Atmospheric Administration, Seattle, WA, p. 12.

Oliveira, O.M.C., 2000. Diagnóstico geoambiental em zonas de manguezal da Baía de Camamu, Ba. Universidade Federal Fluminense, Niterói, Brazil, Doctoral Thesis, p. 249.

Puig, P., Palanques, A., Sanchez-Cabeza, J., Masque, P., 1999. Heavy metals in particulate matter and sediments in the southern Barcelona sedimentation system (North-western Mediterranean). Marine Chemistry $63,311-329$.

Rezende, C.E., Lacerda, L.D., Ovalle, A.R.C., Souza, C.M.M., Gobo, A.A.R., Santos, D.O., 2002. The effect of an oil drilling operation on the trace metal concentrations in offshore bottom sediments of the Campos Basin oil field, SE, Brazil. Marine Pollution Bulletin 44, 680 684.

Sharma, V., Rhudy, K.B., Koening, R., Vazquez, F., 1999. Metals in sediments of Upper Laguna Madre. Marine Pollution Bulletin 38, 1221-1226. 